\title{
KOPI DALAM PERSPEKTIF KESEHATAN
}

\author{
Memperingati hari kopi international 01 oktober \\ Setiyo adi nugroho,Ns. M.Kep \\ Dosen fakultas Kesehatan Universitas Nurul Jadid
}

INDONESIA dikenal surganya kopi dunia, kopi Indonesia juga terbesar ketiga dunia dari sabang sampai merauke komuditi ini ada. Saat ini, konsumsi kafein yaitu kopi menjadi gaya hidup bagi masyarakat modern. Banyak manfaat secara perekonomian dengan peningkatnya konsumsi kopi di Indonesia, beda halnya manfaat secara kesehatan?

Persepsi masyarakat memandang mengkonsumsi kopi berakibat buruk terhadap kesehatan. Persepsi tersebut dibangun tatkala kita sakit pasti petugas kesehatan mengkambing hitamkan konsumsi kopi, ...." kurangi minum kopinya".... "berhenti minum kopinya", " kopi tidak sehat kalau diminum"... dan lain-lain, begitulah para petugas kesehatan menyarankan kepada pasiennya tanpa adanya penjelasan lebih lanjutnya.

Pada kesempatan kali ini kita akan bahas apakah kopi berdampak baik atau buruk buat kesehatan??? Sampai sekarang masih terjadi perdebatan tentang teori kopi dihubungkan dengan kesehatan.

Mari kita tengok dari sisi penelitian yang kaitannya kopi dengan kesehatan, terdapat lebih dari 8000 studi profesional kesehatan dalam 40 tahun terakhir. Kita ambil satu studi terbaru yang dilakukan Roobin poole, dkk tahun 2017 yang berjudul konsumsi kopi dan kesehatan dengan metode metaanalisis. Hasil penelitian tersebut didapatkan bahwa mengkonsumsi kopi pada orang dewasa 3-4 cangkir per hari tidak berdampak negatif pada kesehatan bahkan lebih bermanfaat buat kesehatan, terkecuali wanita yang hamil serta anak-anak.

Dalam penelitian tersebut juga dikutip, bahwa kopi sangrai terdapat lebih dari 1000 senyawa bioaktif, beberapa di antaranya memiliki potensi sebagai antioksidan, antiinflamasi, antifibrotik, dan Senyawa aktif utama termasuk kafein, asam klorogenik, diterpen, cafestol dan kahweol. Semua senyawa aktif ini bermanfaat pada tubuh manusia.

Efek positif konsumsi kopi yang tergolong moderat yaitu 2-4 cangkir per hari dapat mengurangi risiko banyak penyakit. Di antara manfaat kesehatan yaitu :

Tingkatkan kesehatan secara keseluruhan. Sebuah analisis dari hampir 220 studi tentang kopi, yang diterbitkan dalam BMJ pada tahun 2017, menemukan bahwa peminum kopi dapat menikmati manfaat kesehatan secara keseluruhan lebih banyak daripada orang yang tidak minum kopi serta Meningkatkan kinerja fisik kita dan mencerahkan suasana hati kita. Analisis menemukan bahwa selama masa studi, peminum kopi 17 persen lebih rendah untuk meninggal lebih awal dari sebab apa pun, 19 persen lebih kecil untuk meninggal karena penyakit jantung dan 18 persen lebih kecil untuk terserang kanker daripada mereka yang tidak minum kopi.

Meminimalkan kematian akibat penyakit jantung. Pada 2013, jurnal Epidemiology and Prevention menerbitkan studi yang menganalisis korelasi antara konsumsi kopi dengan penyakit kardiovaskular. Data dari 36 studi menunjukkan bahwa orang yang minum tiga hingga lima cangkir kopi per hari memiliki risiko penyakit jantung yang lebih rendah daripada mereka yang tidak minum kopi atau lebih dari lima cangkir per hari. Walaupun alasannya tidak jelas, satu kemungkinan adalah bahwa kopi membantu meningkatkan kontrol pembuluh darah aliran darah atas dan tekanan darah. 
Membakar lemak. Berdasarkan hasil studi secara in vitro dan in vivo yang dilakukan Ksenija Velickovic, dkk didapatkan bahwa konsumsi cafein (minuman kopi) dapat mengaktifkan fungsi Brown adipose tissue (BAT) pada thermoneutrality dan mungkin memiliki potensi untuk digunakan secara terapi pada manusia dewasa untuk menurunkan berat badan.

Mencegah penyakit hati. Beberapa penelitian yang diterbitkan dalam jurnal telah menemukan bahwa minum kopi memiliki efek menguntungkan pada hati, termasuk mengurangi risiko kematian akibat sirosis hati, mengurangi tingkat enzim hati yang berbahaya dan membatasi jaringan parut pada hati orang yang memiliki hepatitis $\mathrm{C}$.

Pencegah terjadinya melanoma atau kanker. Sebuah studi baru-baru ini muncul dalam Journal of National Cancer Institute mengamati kebiasaan minum kopi lebih dari 447.000 orang selama 10 tahun. Para peneliti menemukan bahwa mereka yang minum empat atau lebih cangkir kopi berkafein setiap hari memiliki risiko 20 persen lebih rendah terkena melanoma dibandingkan orang yang minum kopi tanpa kafein atau tanpa kopi.

Meminimalkan risiko penyakit Parkinson. Sejumlah penelitian telah menyarankan bahwa mengonsumsi kafein dapat mengurangi risiko Anda terkena penyakit Parkinson dan penelitian yang diterbitkan pada tahun 2012 di jurnal American Academy of Neurology menunjukkan bahwa dosis harian kafein setara dengan yang ditemukan dalam dua cangkir kopi hitam, dan kopi $t$ dapat membantu mengendalikan pergerakan tak sadar bagi orang-orang yang sudah memiliki penyakit ini.

Mengurangi risiko diabetes tipe II. Sebuah studi tahun 2014 oleh para peneliti Harvard yang diterbitkan dalam jurnal Diabetologica melacak hampir 124.000 orang selama 16-20 tahun. Mereka yang meningkatkan asupan kopi lebih dari satu cangkir sehari selama periode empat tahun memiliki risiko 11 persen lebih rendah terkena diabetes tipe 2 . mereka yang mengurangi asupannya sebanyak satu cangkir per hari memiliki risiko 17 persen lebih tinggi terkena penyakit ini.

Mengurangi risiko demensia dan melindungi pikiran kita. Dalam sebuah studi 2012 yang diterbitkan dalam Journal of Alzheimer's Disease, para peneliti Florida menguji kadar kafein dalam darah pada orang dewasa yang lebih tua dengan gangguan kognitif ringan, yang dapat menjadi awal dari demensia parah, termasuk penyakit Alzheimer. Ketika para peneliti mengevaluasi kembali subjek dua hingga empat tahun kemudian, mereka yang kadar darahnya mengandung jumlah kafein yang setara dengan sekitar tiga cangkir kopi jauh lebih kecil kemungkinannya untuk mengalami demensia daripada mereka yang hanya mengonsumsi sedikit atau tanpa kafein.

Membantu kita melawan depresi dan meminimalkan risiko bunuh diri hingga $\mathbf{5 0 \%}$. Studi yang dilakukan secara metaanalisis pada 330.677 pertisipan menunjukan hasil bahwa Konsumsi kopi dan kafein secara signifikan dalam menurunkan risiko depresi.

Sekarang kita sudah mengetahui bahwa konsumsi kopi itu juga menyehatkan asal tidak berlebihan sehingga direkomendasikan 2-4 cangkir perhari dan perlu diketahui dari penyampaian diatas merupakan hasil penelitian yang terfokuskan kepada konsumsi kopi saja tanpa kopi dengan pemanis atau campuran apapun atau kebiasaan selain dari pada kopi, seperti merokok dan lain-lain. 